\title{
Василіянське чернецтво перемишльської єпархії: просопографічні характеристики (1739-1783 роки)
}

ZARYS TREŚCI: $\quad$ W artykule autor zaprezentował wyniki badań prozopograficznych nad bazylianami z eparchii przemyskiej z klasztorów działających w latach 1739-1783. Omówione zostały pochodzenie, wykształcenie świeckie, wiek, etapy formacji duchowej i intelektualnej, mobilność, obowiązki monastyczne i kościelne członków badanej grupy. Do artykułu dołączono materiał statystyczno-pomocniczy

SŁoWA KLUCzowe: prozopografia, bazylianie, eparchia przemyska, monastyr, rezydencja, prowincja

ABSTRACT:

The author presents the results of prosopographic studies on the Basilians of the Przemyśl eparchy in the monasteries operating in 1739-1783. The paper discusses the origin, secular education, age, stages of spiritual and intellectual formation, mobility, as well as monastic and church duties of the investigated group. Statistical and auxiliary material has been appended to the article.

KEYWORDS: prosopography, Basilians, Przemyśl eparchy, monastery, residence, province

В сучасній українській церковній історіографії основний акцент робиться на вивчення інституційного розвитку монастирів, в той час як поза увагою дослідників перебуває постать самого монаха, а зокрема, вивчення його особистісний характеристик: походження (територіальне, соціальне, 
етноконфесійне), світська освіта, вікові показники (вік вступу, тривалість служіння в Чині, загальний вік), етапи духовної та інтелектуальної формації (кандидат, новик, профес, студент, ієромонах), мобільність чернецтва. Такий підхід, очевидно, зумовлений наявністю досить фрагментарних спеціальних джерел, які в більшості випадків не дають можливості досліднику відповісти на ряд питань.

Для проведення дослідження використано каталоги монастирів та ченців Святопокровської провінції Чину Святого Василія Великого (далі ЧСВВ) ${ }^{1}$. Ці каталоги укладалися в різні роки протоігуменами провінції з метою збору статистично-довідкової інформації, необхідної для ефективного управління монашими спільнотами та для звітування перед Апостольським Престолом. Адже в досліджуваний період василіянські монастирі були вилучені із юрисдикції місцевих єпископів, митрополитів та переведенні у пряме підпорядкування Папи Римського. Така система управління Унійною Церквою була запозичена із Католицької Церкви. Дослідники Василіянського

Чину віднайшли у Ватиканських архівах та опублікували каталоги монастирів Святопокровської провінції, які надсилалися до Апостольської Престолу в 1754, 1772, 1776 та 1780 роках ${ }^{2}$. Ці досить малоінформативні реєстри доповнює каталог біограм василіянського чернецтва цієї ж провінції, який зберігся до нашого часу в рукописному вигляді та опрацьований автором для укладення словника біограм василіянського чернецтва Перемишльської єпархії ${ }^{3}$.

Розглядувана нами тема дослідження не була об’єктом спеціального вивчення у церковній історіографії. Натомість віднаходимо студії з інституційного розвитку василіянських монастирів Перемишльської єпар$\mathrm{xiï}^{4}$. Тільки поодинокі праці присвячені вивченню чернецтва - як певного

1 Каталоги Святопокровської провінції ЧСВВ (1754, 1772, 1776 pр.), „Записки Чину Святого Василія Великого” (далі: ЧСBВ), Серія II, Секція I, T. XL, Рим: ОО. Василіяни 1979, с. 102-124, 126-142, 154-176.

2 Там само.

3 Ю. Стецик, Василіанське чернецтво Перемишльської єпархії (друга половина XVIII ст.): словник біограм, Жовква: Місіонер, с. 2015-312.

4 Б. Балик, Монастирі Перемиської єпархії за владицтва Ін. Винницького, ЧСВВ, Серія II, Секція II, Т. ІІІ, Рим: ОО. Василіяни, 1958, с. 69-97; М. Ваврик, По василіянських манастирях, Торонто 1958, с. 286; його ж, Василіянські монастирі в Перемиській землі // Перемишль. Західний бастіон України. Збірник матеріалів до історії Перемишля 
духовного прошарку суспільства ранньомодерної доби, однак пов'язані з іншими теренам України ${ }^{5}$. В сучасній польській церковній історіографії спостерігається тенденція розвитку просопографічних досліджень католицького чернецтва середньовічного та нового періодів історії Речі Посполитої ${ }^{6}$ Відповідно адаптація новітніх європейських наукових методологій у сучасній українській церковній історіографії дозволить з іншої точки зору розглянути історію Церкви та монастирів Київської унійної митрополії.

В даній статті ставимо собі за мету, вивчивши біограми чернецтва, узагальнити соціальні, територіальні, вікові та освітні характеристики, які в подальшому слугуватимуть основою для проведення комплексного просопографічного дослідження.

Перед тим, як розпочати розгляд характеристик василіянського чернецтва, слід зупинитися на підставовій інформації про чисельність монастирів і ченців. До складу Святопокровської провінції, утвореної в 1739 р. увійшли 130 монастирів та 700 ченців із теренів новоприєднаних єпархій (Луцької, Львівської, Перемишльської) до Київської унійної митрополії. Зокрема, серед них дослідники нараховують 65 монастирів та 300 ченців із Львівської (52 обителі) та Перемишльської (13 обителей) єпархій ${ }^{7}$.

Також слід зауважити, що більшість монастирів Перемишльської унійної єпархії одразу ж на Львівській капітулі (1739) заявили про входження до нового адміністративно-територіального утворення - Святопокровська провінція: Добромиль, Дережичі, Лаврів, Лішня, Летня, Перемишль, Стрий, Спас, Самбір, Топільниця, Улюч, Чернелява, Щеплоти, Сушиця Велика. Проте менша частина монастирів Перемишльської єпархії (Білина Велика, Дорожів, Рибник, Яжів Старий), очевидно через упередженість та зволікання ігуменів, зголосилися на входження до провінції значно пізніше, зокрема під час проведення Дубнівської капітули (1743). Таким чином, усі

та Перемиської землі. Під редакцією проф. Б. Загайкевича, Ню-Йорк- Філадельфія 1961, c. 86-96.

5 М. Яременко, Київське чернецтво XVIII ст., К.: Вид. дім «Києво-Могилянська академія», 2007, с. 304.

6 M. Derwich, Klasztor a miasto w średniowieczu w historiografii europejskiej. Próba podsumowania, [w:] Klasztor w mieście średniowiecznym i nowożytnym, Wrocław 2000, s. 21-50.

7 М. Ваврик, Нарис розвитку і стану Василіянського Чину XVII-XX cm. Топограббічно-статистична розвідка, ЧСВВ, Серія II, Секція I, Т. Х, Рим: ОО. Василіяни 1979, с. 24. 
монастирі Перемишльської єпархії поступово увійшли до Святопокровської василіянської провінції ${ }^{8}$

Нажаль, до нашого часу збереглися візитаційні описи тільки не значної частини василіянських монастирів із теренів Перемишльської єпархії за 1739 - 1740 рр., які не відображують всієї чисельності обителей та чернецтва (дивись додаток I). За структурою вони є досить фрагментарними: подано персональні дані про насельників та загальну статистику прибутків і видатків ${ }^{9}$.

Після утворення Святопокровської провінції та визначення і затвердження в Римі їі статусу у Василіянському Чині Святого Василія Великого постала проблема впорядкування монастирських фундацій. У порівнянні з Святотроїцькою (Литовською) провінцією, в Святопокровській (Польській) провінції, зокрема в Перемишльській єпархії, були поширені дрібні монастирі, де, в середньому, проживали 5- 6 ченців. До 1744 р. ліквідовано кілька найменших чернечих осередків, деколи навіть із одноосібною обсадою (Крушельниця, Лука, Лісько). Найбільшими на 1747 р. на теренах Перемишльської єпархії були монастирі в Добромилі та Лаврові, де проживало більше 20 ченців (дивись додаток I) ${ }^{10}$.

Очевидно, що в малих монастирях, які мали досить бідні фундації, монахи утримували себе із власної господарської праці, тому в таких обителях вже не було й мови про організацію життя відповідно до правил. Тому в 1744 р. папа Бенедикт XIV, затверджуючи постанови Дубенської капітули, доручив митрополитові, щоб він із верховною владою Чину провів реорганізацію монастирів Святопокровської провінції, аби вони нараховували принаймні по 8 монахів. Призначена комісія з цього питання зібралася 1745 р. на Дубенську нараду і на підставі наданих їй документів про прибутки монастирів провінції постановила залишити як самостійні тільки ті обителі, які могли дати утримання для 8 осіб. Решту монастирів

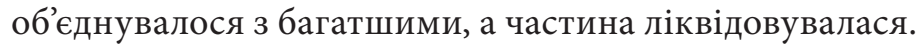

До першої категорії із теренів Перемишльської єпархії потрапили Лаврівський, Добромильський, Лішнянський, Щеплотський монастирі. Саме до них мали бути прилучені менші обителі, яких зараховано до другої

8 I. Патрило, Нарис історії Василіян 1743-1839 рр., ЧСВВ, Серія II, Секція I, T. XLVIII, Рим, 1992, с. 194-197.

9 Державний архів Тернопільської області (далі: ДАТО), Ф. 258, Оп. 3, Спр. 1194, 30 арк.

10 М. Ваврик, Нарис розвитку і стану, с. 28. 
категорії: до Лаврова - Спас та Топільниця; до Добромиля - резиденція із церквою Св. Івана в Перемишлі; до Лішні - Летня, Дережичі, Білина; до Щеплот - Чернилява та Смільниця.

До третьої категорії належали монастирі, які підпадали під ліквідацію, a їх надбання передавалися у відання найближчих обителей. Так, фундації ліквідованих в Перемишльській єпархії осідків Брюховиця, Улюч, Колодка, Накло, Стрий передавалися у відання Добромильського монастиря; Яжів Старий в 1764 р. переданий до Черниляви; Дорожів та Лужок Долішній передано у відання перемишльських єпископів як парафіяльні храми ${ }^{11}$.

У подальшому помітною тенденцією розвитку василіянських монастирів Перемишльської єпархії впродовж другої половини XVIII ст. було скорочення чисельності чернечих осередків, шляхом об ‘ $є$ днання їх із більшими монастирями. Проект про об єднання василіянських монастирів у Святопокровській провінції укладено на вищезгаданій Дубенській нараді (1745), який впроваджувався в життя протягом другої половини XVIII ст. під ревним контролем Риму.

Так, у 1748 р. Апостольська Столиця вислала анкету для Святотроїцького та Святопокровського протоігуменів, зажадавши докладніших звітів про стан монастирів. Протоігумен Сильвестр Коблянський до своєї обширної відповіді на запропоновану анкету долучив табель підлеглих монастирів. У ньому було вміщено 38 монастирів та приєднаних до них 60 резиденцій Святопокровської провінції. Проте відомо, що, окрім вищезгаданих монастирів, продовжували існувати дрібні чернечі осідки 3-поміж тих, що були призначені до ліквідації або ще раніше виявилися не зареєстрованими в укладених списках Дубенської наради ${ }^{12}$.

На прикладі Перемишльської єпархії бачимо, що запропонований процес укрупнення дрібних монастирів набув затяжного характеру. Нерідко в дрібних монастирях, які мали підлягати ліквідації та перебували без зв’язку із іншими обителями, ченці не хотіли переходити до інших осередків, хоча не були спроможні утримувати власну обитель, чи (в іншому випадку) не бажали приймати до себе ченців із розформованих осередків. Ще більше була утруднена справа для монастирів, ліквідації яких противилися фундатори чи їхні спадкоємці, які із входженням василіянських монастирів

11 Львівська національна наукова бібліотека ім. В. Стефаника (далі: ЛННБ), Відділ рукописів, Ф. 3, Спр. 1381/3, Арк. 2.

12 М. Ваврик, Нарис розвитку і стану, с. 25. 
до провінції втратили своє право патронату над фундованими обителями у власних дрібношляхетських посілостях.

Процес ліквідації дрібних монастирів на певний час спричинив безлад серед чернецтва. Зокрема, ряд монахів із ліквідованих осередків удаються до мандрування із монастиря до монастиря без відповідної на це потреби. Провадили, таким чином, досить свавільний спосіб життя та уникали зверхності будь-якого ігумена, оскільки вони не мали сталого місця проживання. За таких обставин Апостольська Столиця прийняла ще один декрет від 27.03.1754 р. про об`єднання малих монастирів, які не мали достатніх фундацій для утримання 8 ченців. Також зазначалося, що потрібно посилити дисципліну в монастирях. Зокрема, пропонувалися шляхи вирішення актуальної для того часу проблеми міграцій ченців із монастиря в монастир. Рекомендувалося обмежити відсилання ченців до інших обителей тільки в церковних справах, а не у власних, із виділенням на дорогу грошей та наданням відповідного листа ${ }^{13}$.

Порівняльний аналіз статистичних даних каталогів ЧСВВ дозволяє говорити про прогресуючу редукцію монастирів в другій половині XVIII ст. Протягом 1754 - 1773 рр. у провінції чисельність монастирів зменшилася на 20 осередків, внаслідок скасування незадовільних фундацій згідно з директивами Апостольської Столиці. Станом на 1754 р. на теренах єпархї̈ діяло 11 монастирів та резиденцій в яких мешкало 119 монахів. I внаслідок запровадження реформ їх чисельність на 1773 р. скоротилася до 9 монастирів та 77 ченців, а на 1778 р. їх кількість скоротилася до 6 обителей із збереженням сталої кількості насельників (дивись таблиия I).

На підставі рішень Тороканської капітули (1780 р.) монастирі єпархії були передані до новоутвореної Святоспаської (Галицької) провінції, яка у 1783 р. була розділена на дві єпархіальні провінції (Львівську, Перемишльську). Однак, ці провінції діяли не тривалий час, оскільки у 1785 р. відбулося їх об’єднання. У результаті проведених австрійською владою релігійних реформ василіянські монастирі були повернуті у юрисдикцію місцевих єпископів, хоча інститут протоігуменату зберігався із значно обмеженими функціями. У 1783 р. до Перемишльської чернечої провінції, окрім єпархіальних монастирів (Добромиль, Дрогобич, Лаврів, Спас, Чернилява, Щеплоти) увійшли обителі із сусідньої Холмської єпархї̈ (Замостя,

\footnotetext{
13 Там само, с. 30 .
} 
Верхрата, Деревляни, Кристинопіль). Це збільшило кількісні показники: монастирів до 10 осередків, насельників до 124 осіб (дивись додаток I).

Розглянувши кількісні показники монастирів і чернецтва, варто звернути увагу на якісний склад монастирських спільнот василіанських осередків Перемишльської єпархії другої половини XVIII ст., оскільки із цього періоду збереглися опубліковані та рукописні каталоги монастирів та чернецтва. В середньому, по обителях єпархії мешкали ченці віком від 22 до 75 років. Час висвячення, відповідно до Конституції ЧСВВ, охоплював вік від 21 до 25 років. Проте маємо поодинокі випадки ранішого вступу до ЧСВВ (в 16 - 19 років) та і пізнішого (40 - 50 років). Таким чином, у монастирях були як досить молоді за стажем ченці - від 2 до 7 років перебування в Чині (таких була меншість), так і досвідчені ченці, які протягом 20 40 років перебували в ЧСВВ. Таке співвідношення певною мірою впливало як на духовне, так і на моральне формування нового покоління василіянського чернецтва. Більшість ченців за своїм соціальним походженням були вихідцями із дрібношляхетських та міщанських родів Перемишльської землі. Проте із утворенням Святопокровської провінції ЧСВВ помітна тенденція до заселення місцевих монастирів вихідцями із простих селянських родів та з інших країв Речі Посполитої - Волині, Поділля та земель Руського воєводства (Львівської, Галицької, Холмської) ${ }^{14}$. Із входженням до Австрійської імперії (1772 р.) нова світська влада зобов'язувала настоятелів монастирів звертати увагу на територіальне походження насельників обителі. Зокрема, заборонялося приймати у чернецтво вихідців із інших країв, які не входили до складу Австрійської імперії. Відповідно у звітах за 1783 p. про персональний склад чернечих спільнот вказувалися відомості про місце народження та термін перебування у Галичині (дивись додаток II). Настоятелям світська влада рекомендувала відправляти монахів із інших земель, які проживали у Галичині не тривалий час, до василіянських монастирів Польського королівства. Категорично заборонявся обмін ченцями між Святоспаською (Галицькою) та Святопокровською (Польською) провінціями. Мобільність монахів допускалася тільки в межах однієї провінції. Такі заборони значно утруднювали підтримання зв'язку із Генеральною Управою Чину, яка знаходилася на території Польського королівства ${ }^{15}$.

14 ЛННБ, Відділ рукописів, Ф. 3, Спр. 614.

15 S. Nabywaniec, Diecezja przemyska greckokatolicka w latach 1772-1795, „Premislia Christiana”, t. 5, 1992/1993, s. 241. 
Щодо якісного складу монастирської братії василіянських монастирів Перемишльської єпархії другої половини XVIII ст. зауважимо, що істотну перевагу в ньому мали ієромонахи у порівнянні з братією. Для прикладу подаємо динаміку чисельності особового складу Лаврівського монастиря впродовж другої половини XVIII ст.: 1754 р. - 18 отців, 9 братів; 1772 p. - 11 отців, 9 братів; 1776 р. - 11 отців, 9 братів; 1780 р. - 10 отців, 7 братів; 1782 р. - 14 отців, 7 братів; 1783 р. - 13 отців, 7 братів ${ }^{16} .3$ огляду на подану інформацію, мають рацію ті дослідники, які стверджують, що в цей час ЧСВВ був суто капеланським згромадженням ${ }^{17}$.

Чисельність чернечої братії знаходилася в прямій залежності від розмірів фундацій та обов’язків, які покладалися на певний осередок. Так, найбагатолюднішими на теренах Перемишльської єпархії були ті монастирі, при яких провадилися різні чернечі студії. Зокрема, Лаврівський та Добромильський монастирі протягом другої половини XVIII ст. налічували від 13 до 27, а деколи 38 ченців. Надалі в дрібніших монастирях (Спас, Щеплоти, Чернилява, Лішня, Дережичі) чисельність монастирської братії коливалася в різний час від 6 до 13 ченців. Найменші чернечі спільноти діяли по монастирських резиденціях (Топільниця, Білина, Летня) де, в основному, мешкало від 2 до 5 монахів ${ }^{18}$. Загалом, на 1783 р. у Перемишльській чернечій провінції нараховувалося 120 монахів, в той час як матеріальне забезпечення обителей, відповідно до фундаційної документації, було розраховане на 185 насельників (дивись додаток III). Зменшення чисельності покликань до чернецтва, було зумовлена релігійною політикою австрійської влади. Зокрема, австрійське законодавство забороняло приймати до чернечого стану юнаків яким не виповнилося 25 років. Тільки після 25 років кандидат міг скласти аскетичні обіти професа ${ }^{19}$.

Нестабільність складу чернечих спільнот була зумовлена тогочасною практикою постійних переїздів ченців із монастиря в монастир чи то з метою проходження студій, чи то для проведення освітніх викладів, чи то для виконання інших духовних обов’язків.

Розглянемо освітні характеристики василіянського чернецтва. До монастирів приходили кандидати з різним рівнем освітньої підготовки,

\footnotetext{
16 Каталоги Святопокровської, с. 102-124; 126-142; 154-176.

17 B. Lorens, Bazylianie prowincji koronnej w latach 1743-1780, Rzeszów 2014.

18 Каталоги Святопокровської, с. 102-124; 126-142; 154-176.

19 S. Nabywaniec, op. cit, s. 242.
} 
яку вони здобули ще у світському житті. Найбільш підготовленими до чернечого стану були світські ієреї-вдівці та семінаристи, які володіли необхідною богословською освітою. Проте і для цієї категорії не ліквідовувалася необхідність духовних випробовувань у школі новіціату, яку завершували складенням аскетичних обітів професа (чистоти, убогості, послуху).

Іншу категорію кандидатів становили випускники або ж учні василіянських колегіумів для світської молоді, які завершили або клас риторики, або синтаксису чи поетики.

Наступну освітню групу складали учні, що навчалися в інших католицьких колегіумах для світської молоді, які утримували єзуїти, піари. Проте найбільш кількісно представлені ті кандидати, які утримали початкову освіту у місцевих парафіяльних школах, вміючи читати та співати по-руськи, і тільки окремі із них вміли писати рідною мовою. Однак при вступі до монастиря найбільша увага зверталася на вміння читати та співати по Ірмолою. Тобто, на перше місце ставилася музична грамота. Про це засвідчує запис у біографічних довідках, де перед вступом до новіціату визначався рівень грамотності кандидата: якою мовою навчався, де навчався, який клас закінчив, чи вміє читати, писати, співати. Рівень грамотності визначався умінням співати, читати та писати. Більшість кандидатів відзначенні як хористи, які очевидно вступали на початках до монастиря як співаки у монастирському хорі, де отримували можливість проявити свої здібності та водночас отримати духовну підготовку для вступу до школи новіціату.

Ще іншу категорію становили діти ремісників, які з дитинства отримували виробничі знання та навички, і вже в юнацькому віці ставали майстрами із різних професій (швець, кравець, панчішник, муляр, столяр, рільник, годинникар, слюсар, коваль, гравер, золотар, скульптор, маляр, музикант). Із набутою професійною освітою вони вступали до

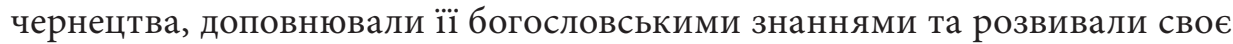
ремесло у монастирському господарстві, яке потребувало фахівців різного профілю ${ }^{20}$.

Відповідно до укладених біограм василіянського чернецтва, вдалося віднайти відомості про здобуту освіту ще у світському житті. Значна їхня кількість встигла завершити навчання у класі риторики, філософії, теології. Адже ці три класи ставали доброю основою для переходу до аскетичного

20 ДАТО, Ф. 258, Оп. 3, Спр. 1194, 30 арк. 
життя, де вони продовжували чернечі студії із цих самих предметів на більш поглибленому рівні. Іншу групу становили випускники класів поетики, синтаксису, логіки, граматики та співу, права, малюнку, фізики.

Рекрутанти перед вступом у чернецтво робили вагомий акцент на здобутті відповідної освітньої підготовки у світському періоді свого життя. Адже для провадження місіонерської та душпастирської праці чернецтва необхідно було володіти певним інтелектуальним рівнем підготовки для виголошення проповідей, відправлення літургій. Відповідно більшість кандидатів не обмежувалися завершенням класів інфіми (початкової школи), а намагалися завершити хоча 6 риторику, філософію, а в кращому випадку теологію, які у подальшому допомагали їм здобувати повну духовну освіту, необхідну для отримання ієрейських свячень

Відповідно до постанов Замойського собору (1720) на капітулах у Львові (1739) та Дубні (1743) василіяни присвятили чимало зусиль вихованню молодого покоління. Із цією метою василіянські професори Перемишльської єпархії провадили різноманітні внутрішні студії: у Добромилі (догматичне богослов’я - 1757 - 1771 рр.), Спасі (риторика - 1776/77, 1779/80, 1783/84 pp.), Щеплотах (моральна теологія 1770 - 1782 рр. та риторика 1783/84 рр.), Лаврові (богослов'я, філософія та риторика 1740 - 178 рр.). ${ }^{21}$.

Місця провадження чернечих студій не були сталими, оскільки вони зазнавали постійних змін і були пов’язані із загальним станом не тільки василіянських монастирів Перемишльської єпархії, але й всієї Святопокровської провінції. Так, наприклад у Лаврові в 1739 - 1741 рр. започатковано філософські студії разом із моральною теологією, які згодом в 1741 p. перенесено до Гощі. І тільки в 1752 - 1753 рр. відновлено студії з моральної теології та філософії. Однак, у 1754 р. моральну теологію перенесено до Добромиля, а в Лаврові залишено філософські студії до $1767 \mathrm{p}^{22}$.

Кількісний склад монастирських студій характеризується наступними статистичними показниками. Звично, у них навчалося по кілька, а інколи по кількадесят ченців. Рідко коли кількість студентів перевищувала 20 чоловік. У Святопокровській провінції станом на 1754 р. риторику студіювали в Гощі - 6 кліриків, філософію у Луцьку - 3 отці та 7 кліриків, теологію

21 І. Филипчак, Р. Лукань, Центральна Крайова Окружна Головна Школа в Лаврові (1788-1911 рр.), ЧСВВ, Серія II, Секція II, Т. ХІ, Рим: ОО. Василіяни 1967, с. 3.

22 M. Wawryk (OSBM), De studiis philosophico-theologicis in provincia RuthenoUcraina OSBM s. XVIII eorumque manualibus, „Analecta Ordinis Sancti Basilii Magni” (dalej: Analecta OSBM), vol. VII, 1971, s. 85. 
у Львові - 8 отців та 3 клірики. Того ж року 4 клірики із тієї ж провінції студіювали в Римі та по 2 алюмнати - в Браневі та Вільні. Невеликим був і персонал учителів. Студії риторики, як подає інформація за 1774 р., викладав завжди один професор. Філософські студії - 1 - 2 професори. Теологію викладали найчастіше 2 професори ${ }^{23}$.

Окремої уваги заслуговують богословські студії, які діяли в Добромилі впродовж другої половини XVIII ст. Зокрема, в 1758 р. управа Святопокровської провінції видала розпорядження про перенесення вивчення спекулятивно-догматичної теології до Добромильського монастиря ${ }^{24}$. Викладання богослов’я в Добромилі тривало 3 роки. Виклади провадили переважно 2 професори, які навчали в різні роки від 4 до 10 слухачів. У 1771 р. спекулятивне богослов'я із Добромиля було переведено до Лаврова, а згодом, у 1773 р. до Кам'янця-Подільського. У Лаврові було залишено догматичне й моральне богослов'я, яке в 1775 р. переведено до Сатанова, а в Лаврові натомість започатковано студії з риторики для ченців, які згодом доповнено студіями з філософії (від 1776 р.) та догматичного богослов’я (від 1778 р.) ${ }^{25}$.

Про освітній рівень василіянського чернецтва Перемишльської єпархії подає відомості каталог 1766 р.: здобули студії з риторики, філософії, теології та отримали ієрейські свячення - 49 \% ченців; пройшли два напрямки студій - 12 \% ченців; засвоїли тільки один навчальний напрямок - 12 \%енців; не пройшли жодних студій - 27 \% ченців, які виконували господарські обов'язки по монастирських фільварках: кравця, шевця, коваля, тесляра, фіртянина. На підставі біограм можемо визначити основні місця проходження студій: риторика - Щеплоти, Краснопуща, Гоща, Бучач; філософія Лаврів, Замостя, Перемишль (школа отців-єзуїтів), Львів, Теребовля, Добромиль; теологія - Добромиль, Гоща, Львів, Сатанів, Підгірці.

Відповідно до здобутих студій на іноків покладалися різні монастирські обов’язки: освітні (магістр новиків, професор теології, префект школи, катехит), церковні (проповідник, сповідник, місіонер, парох); адміністративні (ігумен, вікарій, консультор, провінціал, секретар, архівіст);

23 L. Bieńkowski, Organizacja Kościoła Wschodniego w Polsce, [w:] Kościół w Polsce, t. 2: Wieki XVII-XVIII, Kraków 1970, s. 1016.

24 Archiwum Państwowe w Przemyślu, Archiwum Greckokatolickiego Biskupstwa w Przemyślu (dalej: AGBP), sygn. 222, s. 127.

25 Центральний державний історичний архів України у м. Львові, Ф. 364, Оп. 1, Спр. 20, Арк. 162. 
господарські (прокуратор (економ), ремісник, префект будови, рільник, садівник, пасічник) ${ }^{26}$.

Василіянський Чин не обмежувався тільки своїми внутрішніми студіями, але й відправляв ченців-студентів на навчання до папських колегіумів, які в той час знаходилися у Вільні, Браунсбургу, Львові, Оломоуці, Празі, Відні, Граці та Римі. Випускники цих папських колегіумів призначалися на керівні посади як в управлінні Чином, так і в керівництві адміністративними одиницями (єпархіями) Київської унійної митрополії.

Зокрема, у Римі діяли два папські колегіуми, в яких навчалися студенти-василіяни: грецька колегія Св. Атанасія та колегія папи Урбана Конгрегації Поширення Віри. У списку випускників колегіуму папи Урбана віднаходимо вихідців із теренів Перемишльської єпархії: 1708 р. - Антоній Винницький, 1733 р. - Цезарій Стебновський, 1739 р. - Августин Новосільський, 1741 р. - Максиміліан Рило, 1747 р. - Ієронім Маркевич, 1747 р. Атанасій Шептицький, 1760 р. - Єротей Корчинський ${ }^{27}$.

Нове покоління чернецтва свій духовний вишкіл проходило впродовж другої половини XVIII ст., в основному, у новіціатах, розташованих у Почаєві та Добромилі. Монах, який пройшов усі ступені чернечого вишколу (кандидат - новик - профес - ієромонах), отримував відповідну духовну та інтелектуальну підготовку. Зокрема, високоосвічені монахи знали по кілька мов: польську, латинську, грецьку, а із кінця XVIII ст. й німецьку. Проте траплялися поодинокі випадки, коли ченці не вміли ані читати, ані писати навіть рідною "руською” мовою. Такі випадки малограмотності траплялися на початках входження монастирів до Святопокровської провінції (1739 - 1747 рр.). І практично впродовж наступних двадцяти років було виховано нове покоління, яке відзначалося здобутими освітніми студіями. Вже у звітах 1783 р. потрапляємо на поодинокі згадки про безграмотність серед рядового чернецтва. Ці згадки відносяться переважно до новоприбулих рекрутантів у монашество 28 .

В процесі проведеного дослідження з'ясовано, що соціальною базою, із якої рекрутувалося чернецтво, були - шляхта, міщани та селяни, які походили із різних теренів Речі Посполитої, а після 1772 р. - циркулів Галицького

26 ЛННБ, Відділ рукописів, Ф. 3, Спр. 435.

27 D. Blazejowskyj, Ukrainian and Bielorussian students in the pontifico collegio Urbano de Propaganda Fide (1627-1846), „Analecta OSBM”, vol. IX, 1974, s. 202.

28 AGBP, sygn. 222, s. 25, 31, 138. 
губернаторства Австрійської імперії, оскільки Святопокровська провінція ЧСВВ охоплювала декілька єпархій Київської унійної митрополії. В загальному по монастирях єпархії проживали ченці віком від 22 до 75 років. Співжиття молодого та старшого поколінь впливало як на духовне, так і на інтелектуальне формування чернецтва. Вагому перевагу в особовому складі монастирської братії мали ієромонахи. Чисельність чернецтва знаходилася в прямій залежності від розмірів фундацій та обов’язків, які покладалися на певний монастир. Освітній рівень чернецтва визначався проходженням студій з риторики, філософії та богослов’я, які здобула більшість чернецтва єпархії.

Хоча кандидати у чернецтво відрізнялися різним рівнем освітньої підготовки, який визначав подальший шлях їхнього духовного, інтелектуального та господарського служіння у монастирських спільнотах, проте здобуття чернечих студій вирівнювало їх статус. Перед вступником до чернецтва не ставилося жодних освітніх вимог. Кандидатом міг бути простий безграмотний селянин або ж високоосвічений ієрей-вдівець чи семінарист. Усі отримували однакові можливості щодо духовного зростання, однак кожний обирав для себе індивідуальний шлях аскетичного служіння, враховуючи власні інетелектуальні здібності та вподобання.

Перспективний напрямок дослідження вбачаємо у віднайдені, опрацюванні та публікації досі невідомих в церковній археографії каталогів монастирів та чернецтва Перемишльської єпархії, особливо із 1783 - 1785 рр., коли на цих теренах діяла окрема чернеча провінція.

Додаток 1

Динаміка чисельності василіянських монастирів та чернецтва Перемишльської єпархії (1739 - 1783 рp.)

\begin{tabular}{|c|c|c|c|}
\hline монастир & отці & брати & разом \\
\hline \multicolumn{4}{|c|}{$1739-1740 p p^{29}$} \\
\hline 1.Брюховиця & 2 & - & 2 \\
\hline 2.Дережичі & 3 & 1 & 4 \\
\hline 3.Добромиль & 21 & 12 & 33 \\
\hline 4.Лаврів & 19 & 12 & 31 \\
\hline
\end{tabular}

29 ДАТО, Ф. 258, Оп. 3, Спр. 1194, Арк. 1-36. 


\begin{tabular}{|c|c|c|c|}
\hline монастир & отці & брати & разом \\
\hline 5.Лішня & 5 & 1 & 6 \\
\hline 6.Стрий & 2 & - & 2 \\
\hline 7.Улюч & 3 & - & 3 \\
\hline 8.Щеплоти & 2 & 11 & 13 \\
\hline $\begin{array}{c}\text { про інші обителі від- } \\
\text { сутні відомості }\end{array}$ & - & - & - \\
\hline Разом - 8 & 57 & 37 & 94 \\
\hline \multicolumn{4}{|c|}{1747 p. $^{30}$} \\
\hline 1.Добромиль & 20 & 16 & 36 \\
\hline 2.Лішня & 4 & 1 & 5 \\
\hline 3.Лаврів & 18 & 4 & 22 \\
\hline 4.Спас & 2 & - & 2 \\
\hline 5.Топільниця & 2 & - & 2 \\
\hline 6.Чернилява & 5 & 2 & 7 \\
\hline 7.Щеплоти & 11 & 4 & 15 \\
\hline $\begin{array}{c}\text { про інші обителі від- } \\
\text { сутні відомості }\end{array}$ & - & - & - \\
\hline Разом - 7 & 62 & 27 & 89 \\
\hline \multicolumn{4}{|c|}{$1754 \mathrm{p}^{31}$} \\
\hline 1.Білина & 3 & - & 3 \\
\hline 2.Глубічок & 3 & - & 3 \\
\hline 3.Дережичі & 5 & 1 & 6 \\
\hline 4.Добромиль & 13 & 25 & 38 \\
\hline 5.Лаврів & 19 & 10 & 29 \\
\hline 6.Летня & 3 & 1 & 4 \\
\hline 7.Лішня & 6 & - & 6 \\
\hline 8.Спас & 6 & 2 & 8 \\
\hline 9.Топільниця & 5 & - & 5 \\
\hline 10.Чернилява & 6 & 2 & 8 \\
\hline 11.Щеплоти & 9 & - & 9 \\
\hline
\end{tabular}

\section{Skrutenia.}

30 Archiwum Polskiej Prowincji Dominikanów w Krakowie, Ławra Poczajowska, sygn. 2,

31 Cathalogus monasteriorum et personarum provinciae protectionis B. V. Mariae Ordinis S. Basilii Magni. Anni 1754, ЧСВВ, Серія II, Секція I, T. XL, Рим 1979, с. 102-124. 


\begin{tabular}{|c|c|c|c|}
\hline монастир & отці & брати & разом \\
\hline Разом - 11 & 78 & 41 & 119 \\
\hline \multicolumn{4}{|c|}{$1773 \mathrm{p}^{32}$} \\
\hline 1.Білина & 4 & 1 & 5 \\
\hline 2.Дережичі із Летнею & 6 & 1 & 7 \\
\hline 3.Добромиль & 14 & 5 & 19 \\
\hline 4.Лаврів & 9 & 11 & 20 \\
\hline 5.Лішня & 4 & 1 & 5 \\
\hline 6.Спас & 4 & 1 & 8 \\
\hline 7.Топільниця & 2 & 1 & 3 \\
\hline 8.Чернилява & 4 & 1 & 5 \\
\hline 9.Щеплоти & 8 & - & 8 \\
\hline Разом - 9 & 55 & 22 & 77 \\
\hline \multicolumn{4}{|c|}{$1778 \mathrm{p}^{33}$} \\
\hline 1.Добромиль & 12 & 5 & 17 \\
\hline 2.Дрогобич & 7 & 5 & 12 \\
\hline 3.Лаврів із Білиною & 9 & 7 & 16 \\
\hline 4.Спас із Топільницею & 6 & 10 & 16 \\
\hline 5.Чернилява & 5 & 1 & 6 \\
\hline 6.Щеплоти & 7 & 3 & 10 \\
\hline Разом - 6 & 46 & 31 & 77 \\
\hline \multicolumn{4}{|c|}{$1783 \mathrm{p}^{34}$} \\
\hline 1.Верхрата & 5 & 1 & 6 \\
\hline 2.Деревляни & 4 & 1 & 5 \\
\hline 3.Добромиль & 14 & 8 & 22 \\
\hline 4.Дрогобич & 7 & 9 & 16 \\
\hline 5.Замостя & 8 & 5 & 13 \\
\hline 6.Кристинопіль & 10 & 2 & 12 \\
\hline
\end{tabular}

32 Cathalogus monasteriorum Ordinis Sancti Basilii Magni provinciae Protectionis Beatissimae Virginis Mariae cum residentibus in iis Religiosis Patribus et Fratribus ex Anno 1773 a Mense Septembri ad Septembrem 1774 Anni, Typis S.R.M. Monaste: Poczajovien: O.S.B.M. Anno Domini 1773.

${ }^{33}$ Cathalogus Professorum Ordinis S. B. Magni provinciae Protectionis Beatissimae Virginis Mariae juxta Ordinem Alphabetici in Monasteriorum ex Anno 1778 in Annum 1779, Typis S.R.M. Monaste: Poczajovien: O.S.B.M. Anno Domini 1778.

34 AGBP, sygn. 222, s. 11, 15, 23, 29, 34, 99. 


\begin{tabular}{cccc}
\hline монастир & отці & брати & разом \\
\hline 7.Лаврів & 15 & 7 & 22 \\
\hline 8.Спас & 5 & 5 & 10 \\
\hline 9.Чернилява & 4 & 2 & 6 \\
\hline 10.Щеплоти & 8 & 4 & 12 \\
\hline Разом - 10 & 80 & 44 & 124 \\
\hline
\end{tabular}

Додаток II

Звіт про персональний склад василіянських монастирів Холмської єпархії, які увійшли до Перемишльської чернечої провінції (23 липня 1783 р.)

\begin{tabular}{|c|c|c|c|c|c|c|c|}
\hline Ім’я, прізвище & Обов'язки & Вік & $\begin{array}{c}\text { Місце } \\
\text { народже-ння }\end{array}$ & $\begin{array}{c}\text { Час } \\
\text { в Гали-чині }\end{array}$ & Новіціат & $\begin{array}{c}\text { Час } \\
\text { в Чині }\end{array}$ & $\begin{array}{c}\text { Знання мов } \\
\text { (без } \\
\text { рус. пол.) }\end{array}$ \\
\hline \multicolumn{8}{|c|}{ Верхрата із резиденцією у Ямниці ${ }^{35}$} \\
\hline $\begin{array}{c}\text { о.Варлаам } \\
\text { Курницький }\end{array}$ & ігумен & 47 & $\begin{array}{c}\text { поза } \\
\text { Галичиною }\end{array}$ & 5 & Почаїв & 24 & латина \\
\hline $\begin{array}{c}\text { о.Антоній } \\
\text { Донбровський }\end{array}$ & вікарій & 67 & $\begin{array}{c}\text { Б.ц. } \\
\text { Старе село }\end{array}$ & 10 & Почаїв & 35 & латина \\
\hline $\begin{array}{c}\text { о.Леонід } \\
\text { Воронович }\end{array}$ & $\begin{array}{c}\text { про- } \\
\text { повідник }\end{array}$ & 41 & $\begin{array}{c}\text { Л.ц. } \\
\text { Городок }\end{array}$ & 6 & Почаїв & 14 & латина \\
\hline $\begin{array}{c}\text { о.Филемон } \\
\text { Гарасимович }\end{array}$ & $\begin{array}{c}\text { парох } \\
\text { у Ямниці }\end{array}$ & 41 & $\begin{array}{c}\text { поза } \\
\text { Галичиною }\end{array}$ & 5 & Почаїв & 6 & ніякої \\
\hline $\begin{array}{c}\text { о.Макарій } \\
\text { Божовський }\end{array}$ & $\begin{array}{c}\text { сповідник } \\
\text { ризник }\end{array}$ & 50 & $\begin{array}{c}\text { поза } \\
\text { Галичиною }\end{array}$ & 10 & Почаїв & 26 & ніякої \\
\hline $\begin{array}{c}\text { бр.Андронік } \\
\text { Бориславський }\end{array}$ & $\begin{array}{c}\text { піддиякон } \\
\text { послушник }\end{array}$ & 31 & $\begin{array}{c}\text { П.ц. } \\
\text { Борислав }\end{array}$ & 10 & Добромиль & 10 & ніякої \\
\hline \multicolumn{8}{|c|}{ Деревляни $^{36}$} \\
\hline $\begin{array}{c}\text { о.Арсеній } \\
\text { Новосілецький }\end{array}$ & ігумен & 54 & $\begin{array}{c}\text { поза } \\
\text { Галичиною }\end{array}$ & 5 & Почаїв & 34 & латина \\
\hline $\begin{array}{c}\text { о.Веніамін } \\
\text { Пасюта }\end{array}$ & парох & 67 & $\begin{array}{c}\text { поза } \\
\text { Галичиною }\end{array}$ & 13 & Почаїв & 34 & ніякої \\
\hline $\begin{array}{c}\text { о.Варлаам } \\
\text { Онсаковський }\end{array}$ & ризник & 60 & $\begin{array}{c}\text { поза } \\
\text { Галичиною }\end{array}$ & 16 & Почаїв & 30 & ніякої \\
\hline $\begin{array}{c}\text { о.Діонісій } \\
\text { Головацький }\end{array}$ & місіонер & 69 & $\begin{array}{c}\text { поза } \\
\text { Галичиною }\end{array}$ & 4 & Мільці & 50 & ніякої \\
\hline $\begin{array}{c}\text { бр.Лампадій } \\
\text { Маркевич }\end{array}$ & послушник & 57 & $\begin{array}{c}\text { поза } \\
\text { Галичиною }\end{array}$ & 6 & Почаїв & 9 & ніякої \\
\hline
\end{tabular}

35 Ibidem, sygn. 202, s. 288.

36 Ibidem, s. 291. 


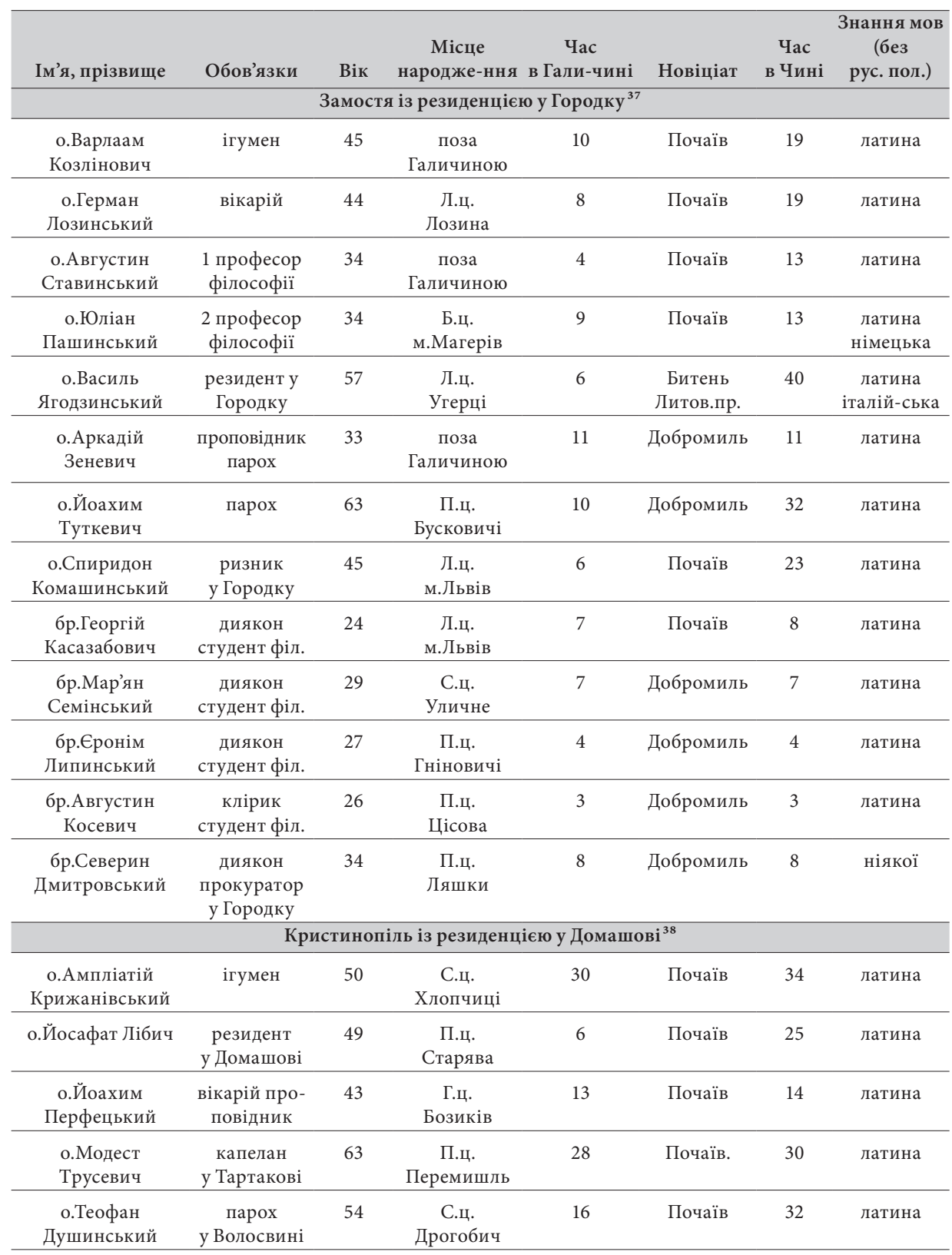

37 Ibidem, s. 289.

38 Ibidem, s. 290. 


\begin{tabular}{|c|c|c|c|c|c|c|c|}
\hline Ім'я, прізвище & Обов'язки & Вік & $\begin{array}{c}\text { Місце } \\
\text { народже-ння }\end{array}$ & $\begin{array}{c}\text { Час } \\
\text { в Гали-чині }\end{array}$ & Новіціат & $\begin{array}{c}\text { Час } \\
\text { в Чині }\end{array}$ & $\begin{array}{c}\text { Знання мов } \\
\text { (без } \\
\text { рус. пол.) }\end{array}$ \\
\hline $\begin{array}{c}\text { о.Ка- } \\
\text { сіян Дзедзіцький }\end{array}$ & парох дому & 29 & $\begin{array}{c}\text { Жешів } \\
\text { Канчуга }\end{array}$ & 6 & Добромиль & 6 & латина \\
\hline $\begin{array}{c}\text { о.Діонісій Геру- } \\
\text { шинський }\end{array}$ & $\begin{array}{c}\text { парох } \\
\text { у Городищі }\end{array}$ & 54 & $\begin{array}{c}\text { Л.ц. } \\
\text { м.Миколаїв }\end{array}$ & 32 & Крехів & 32 & ніякої \\
\hline $\begin{array}{c}\text { o.Іполит Сто- } \\
\text { кальський }\end{array}$ & ризник & 39 & $\begin{array}{c}\text { Дром- } \\
\text { бов-ленін } \\
\text { Богатківці }\end{array}$ & 10 & Почаїв & 11 & латина \\
\hline $\begin{array}{c}\text { o.Інокентій Кули- } \\
\text { ковський }\end{array}$ & $\begin{array}{c}\text { ризник } \\
\text { у Домашові }\end{array}$ & 53 & $\begin{array}{c}\text { Яворів } \\
\text { Яжів }\end{array}$ & 18 & Почаїв & 25 & ніякої \\
\hline о.Антоній Струс & $\begin{array}{l}\text { прокуратор } \\
\text { у Домашові. }\end{array}$ & 53 & $\begin{array}{c}\text { поза } \\
\text { Галичиною }\end{array}$ & 4 & Почаїв & 12 & ніякої \\
\hline $\begin{array}{c}\text { бр.Адам } \\
\text { Юзефович }\end{array}$ & $\begin{array}{c}\text { лаїк } \\
\text { прокуратор }\end{array}$ & 30 & $\begin{array}{l}\text { Самбір } \\
\text { Липиць }\end{array}$ & 10 & Добромиль & 10 & ніякої \\
\hline $\begin{array}{c}\text { бр.Северин } \\
\text { Дмитровський }\end{array}$ & $\begin{array}{c}\text { лаїк } \\
\text { послушник }\end{array}$ & 33 & $\begin{array}{c}\text { Лісько } \\
\text { Махначка }\end{array}$ & 10 & Добромиль & 10 & ніякої \\
\hline
\end{tabular}

Список скорочень у додатку II

Б.ц. - Белзький циркул

Г.ц. - Галицький циркул

Л.ц. - Львівський циркул

П.ц. - Перемишльський циркул

С.ц. - Самбірський циркул

\section{Додаток III}

\section{Порівняльна таблиця чисельності монахів} станом на 12 червня $\mathbf{1 7 8 3} \mathrm{p}^{39}$.

\begin{tabular}{ccc}
\hline монастир & фундація & насельники \\
\hline 1.Білина & 5 & 4 \\
\hline 2.Деревляни & 6 & 5 \\
\hline 3.Добромиль & 34 & 22 \\
\hline 4.Домашів & 6 & 3 \\
\hline 5.Дрогобич & 21 & 3 \\
\hline 6.Городок & 5 & 6 \\
\hline 7.Чернилява & 8 & 6 \\
\hline
\end{tabular}

39 Ibidem, s. 176-178. 


\begin{tabular}{ccc}
\hline монастир & фундація & насельники \\
\hline 8.Кристинопіль & 13 & 10 \\
\hline 9.Лаврів & 27 & 19 \\
\hline 10.Щеплоти & 18 & 6 \\
\hline 11.Спас & 14 & 10 \\
\hline 12.Верхрата & 8 & 6 \\
\hline 13.Замостя & 20 & 10 \\
\hline Разом & 185 & 120 \\
\hline
\end{tabular}

\section{Summary}

\section{Basilians of the Przemyśl Eparchy in 1739-1783. A Prosopographic Description}

The article stresses the importance of prosopographic studies on the characteristics of the monasticism of the Basilians (Basilian Fathers) of the Przemyśl eparchy (the origin, secular education, age, stages of spiritual and intellectual formation, mobility, monastic and church duties). The paper defines the source base of the studies (catalogues of monasteries and monks, the manuscript catalog of the biographies of Basilian monasticism). The text presents a survey of the achievements of Ukrainian and Polish church historiography with regards to the issues of prosopographic studies, and investigates the dynamics of the Basilian monasteries and their inhabitants in the context of the entry of the ascetic communities in the Przemyśl diocese into the monastic Province of the Holy Protection of the Mother of God`s Order of St. Basil the Great. The author traces the process of reorganization of monastic centers in the Przemyśl diocese in the second half of the 18th century and specifies the consequences of the closedown of small monasteries. Attention is drawn to the numerical and qualitative composition of the monastic Przemyśl Province as of 1783 . The paper defines the prospective direction of further research: to find and edit the catalogues of the manuscripts of monasticism. Appended to the article is the statistical and auxiliary material: Appendix I. Dynamics of the number of Basilian monasteries and numerical strength of monasticism in the Przemyśl diocese (1739-1783); Appendix II. A Report on the personal composition of the Basilian monasteries in the Chełm diocese, which became part of the monastic Przemyśl Province on 23 July 1783; Appendix III. A Comparative table of the number of monks as of 12 June 1783 . 


\section{Bibliografia}

\section{Źródła drukowane}

Cathalogus monasteriorum et personarum provinciae protectionis B. V. Mariae Ordinis S. Basilii Magni. Anni 1754, ЧСВВ, Серія II, Секція I, Т. XL, Рим 1979.

\section{Literatura}

Bieńkowski L., Organizacja Kościoła Wschodniego w Polsce, [w:] Kościół w Polsce, t. 2: Wieki XVII-XVIII, Kraków 1970.

Балик Б., Монастирі Перемиської єпархї̈ за владицтва Ін. Винницького, „Записки Чину

Святого Василія Великого”, Серія II, Секція II, Т. III, Рим: ОО. Василіяни, 1958, с. $69-97$.

Blazejowskyj D., Ukrainian and Bielorussian students in the pontifico collegio Urbano de Propaganda Fide (1627-1846), „Analecta OSBM”, vol. IX, 1974.

Ваврик М., По василіянських манастирях, Торонто 1958;

Ваврик М, Василіянські монастирі в Перемиській землі // Перемишль. Західний бастіон України. Збірник матеріалів до історії Перемишля та Перемиської землі. Під редакцією проф. Б. Загайкевича, Ню-Йорк- Філадельфія 1961.

Ваврик М., Нарис розвитку і стану Василіянського Чину XVII-XX cm. Tonoгpaфiчно-статистична розвідка, „Записки Чину Святого Василія Великого”, Серія II, Секція I, Т. Х, Рим: ОО. Василіяни 1979.

Wawryk M. (OSBM), De studiis philosophico-theologicis in provincia RuthenoUcraina OSBM s. XVIII eorumque manualibus, „Analecta Ordinis Sancti Basilii Magni” (dalej: Analecta OSBM), vol. VII, 1971.

Derwich M., Klasztor a miasto w średniowieczu w historiografii europejskiej. Próba podsumowania, [w:] Klasztor w mieście średniowiecznym i nowożytnym, Wrocław 2000, s. 21-50.

Каталоги Святопокровської провінції ЧСВВ (1754, 1772, 1776 рр.), „Записки Чину Святого Василія Великого”, Серія II, Секція I, Т. XL, Рим: ОО. Василіяни 1979, с. 102-124, 126-142, 154-176.

Lorens B., Bazylianie prowincji koronnej w latach 1743-1780, Rzeszów 2014.

Nabywaniec S., Diecezja przemyska greckokatolicka w latach 1772-1795, „Premislia Christiana”, t. 5, 1992/1993.

Патрило I., Нарис історії Василіян 1743-1839 рр., „Записки Чину Святого Василія Великого”, Серія II, Секція I, T. XLVIII, Рим, 1992. 
Стецик Ю., Василіанське чернецтво Перемишльської єпархії (друга половина XVIII ст.): словник біограм, Жовква: Місіонер, с. 2015-312.

Филипчак I., Р. Лукань, Центральна Крайова Окружна Головна Школа в Лаврові (1788-1911 рр.), „Записки Чину Святого Василія Великого”, Серія II, Секція II, Т. ХІ, Рим: ОО. Василіяни 1967.

Яременко М., Київське чернецтво XVIII ст., К.: Вид. дім «Києво-Могилянська академія», 2007. 